\title{
Construction of the fortified series of Cossack strongholds and village of Paris
}

\author{
Elena Ponomarenko ${ }^{1,2, *}$ \\ ${ }^{1}$ Scientific Research Institute of the Theory and History of Architecture and Urban Planning, branch \\ of the Central Institute for Research and Design of the Ministry of Construction and Housing and \\ Communal Services of the Russian Federation, 111024 Moscow, Dushinskaya Street, 9, Russia \\ ${ }^{2}$ Architecturally-building Academy Samara State Technical University, 443001, Samara, \\ Molodogvardeiskaya Street, 194, Russia
}

\begin{abstract}
The issue topicality is due to the increasing interest in architectural traditions of the Russian regions. The research objective is to identify the main development stages and features of the Cossack stanitsa (settlement) Paris of Novolineyniy region of Orenburg gubernia and evolution of architectural forms. The leading research method was historical-architectural analysis and summarization of archive and field data. A staged analysis of development of this type of settlements was performed. Descriptions and analysis of little-known architectural monuments of the region are presented. The paper reveals an interesting stratum of regional heritage. The article attempts to analyze a wide range of issues related to the formation of the architecture of the Cossack stanitsas (settlements) in the Novolineyniy region of Orenburg gubernia in the 19th-20th centuries. The layout, composition and stylistic features of the architecture of the Cossack stanitsas (settlements) in the Novolineyniy region are considered. Numerous materials of central and local archives were researched and are published for the first time.
\end{abstract}

\section{Introduction}

The issue topicality is due to the increasing role of the Russian regions in preserving and restoring the historical environment of settlements, which is why the main results of the research is of utmost importance. The interest in cultural traditions of various groups of the population in the Russian provincial regions is constantly growing. The main source for this research was exploration of the territories of Orenburg gubernia of the middle of the 19th c, which nowadays comprises the modern Chelyabinsk and Orenburg oblasts. This area used to be populated by the Orenburg Cossack troops. We analyzed the data of the central and local archives and museums concerning the materials of the Mining Board, the Senate, the Department of Mines, the Office of Plant Management, Orenburg and Perm mining administrations.

Studying of the Cossack stanitsas of Novolineyniy region of Orenburg gubernia started in the second half of the 19th c almost immediately after they were established, and

\footnotetext{
* Corresponding author: evpon@mail.ru
} 
continued in the end of the 19th - beginning of the 20th cc. Information about these settlements appears in the works by such travelers and ethnographers as V. M. Cheremshanskiy 1859 [1], F. M. Starikov 1881 [2], V. N. Vitevskiy 1882; 1897 [3, 4], P. I. Rychkov 1887 [5], N. M. Chernavskiy 1900 [6]; E. A. Bekteeva 1902 [7], D. K. Zelenin 1905 [8], M. A. Krukovskiy 1909 [9], A. I. Krivoshchekov 1915 [10], also there were a number of articles in Orenburg Eparchial Bulletin Orenburgskiye eparkhialnye vedomosti, 1876, 1911, 1912 [11, 12, 13], During the Soviet period, works by M. D. Golubykh 1930 [14], and E. E. Blomkvist 1956 [15] were published.

\section{Methodological framework}

The research methodology is based on comprehensive historical and architectural analysis. Systemic approach implies historical-genetic, architectural and town-planning analysis (typological, stylistic). Most important is that such approach takes into account numerous aspects of national, confessional, and ethnic diversity of the heritage. The features of development of a multi-national region require paying special attention to the historical and architectural analysis, based on the conception of social ecology. This approach implies an ethic criterion providing the succession of cult architecture quality. To collect field data, we used such methods as: direct inspection and measuring of material remains of buildings, photo survey, in-depth interviews with informers.

\section{Results}

In the first half of the 19th c., the territory of the Southern Urals was largely developed by the Russian population; several fortified series of Cossack strongholds and many factory towns had been built. The fortified series of strongholds divided two nations at war - the Bashkirs and the Kazakhs.

Systematic raids of these nomadic people on each other and on the Cossacks compelled the Russian government to reinforce the defense capacity of the south-eastern boundaries of the Empire [16]. In 1835, a new fortified series of strongholds started to be built according to the plan by an Orenburg military governor V. A. Perovskiy. A broad buffer zone was to appear between the old and the new strongholds to separate the Bashkirs and the Kazakhs, which was called Novolineyniy («new line») region. The zone was to be defended by its residents, so it was inhabited only by the Cossacks. V. A. Perovskiy considered eviction of the Kazakhs from Novolineyniy region to be a fair punishment for their banditry in the boundary lands and for the insubordination to the Russian administration: «arable land is useless for the Kirghiz; they use wood only to warm their tents in winter and in summer they damage woods with fires» [5]. In the studied period, the Kazakhs were called «the Kirghiz-kaysaks» or just «the Kirghiz».

Development began simultaneously from the north and south. The line linked the towns of Orsk and Troitsk (Fig. 1). «The new line started from the town of Orsk, goes in the steppe north-eastward through Orskiy, Verkhneuralskiy and Troitskiy uezds and finishes at stanitsa Berezovskaya on Uya river in Chelyabiskiy uezd» [17]. In 1837, five strongholds were built along the fortified line: Imperatorskaya, Naslednitskaya, Konstantinovskaya, Nikolayevskaya, and Mikhaylovskaya. Only two of them are preserved - Nikolayevskaya and Naslednitskaya.

In the beginning of the 1840-s, 40 Cossack settlements (stanitsa) were founded in the territory of Novolineyniy region. In the spring and summer of 1841, reconnaissance groups determined 32 sites for new settlements, then another 8 were added. Initially, only settlements at the boundary had names. They were named after members of Emperor's 
family or by the church holidays close to the day of foundation of the settlement. Settlements between those in the line were numbered from 1 to 32 . The local residents still remember the initial numbers of many of settlements.

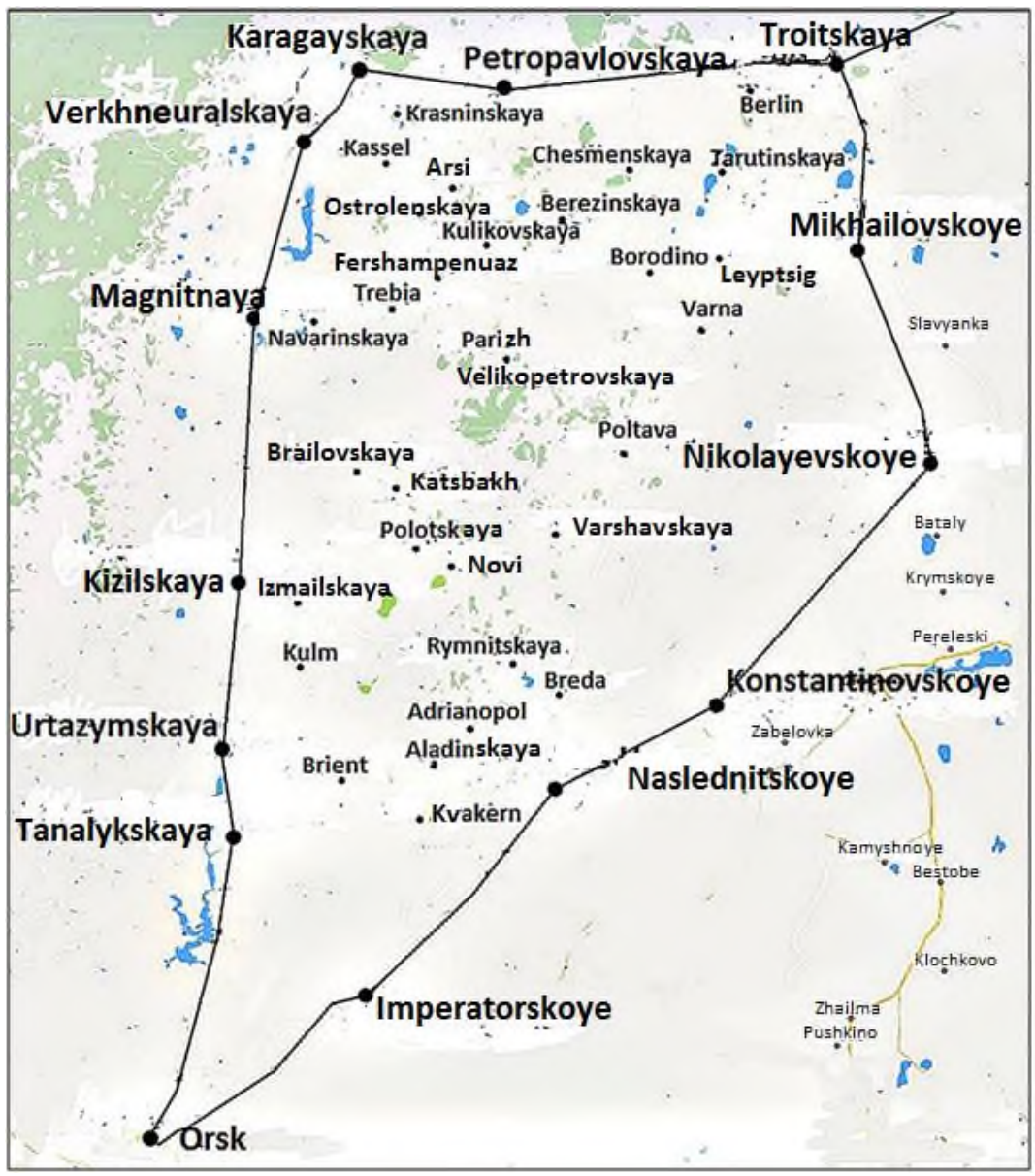

Fig. 1. Map of Novolineyniy region.

At that period, the following stanitsas were founded: Poltavka, Varshavka, Varna, Fershampenuaz, Annenskoye, Rymnitskoye, Borodinovka, Moskva, Parizh, Berlin, Leyptsig, Chesma and others (Fig. 1). These names appeared in Orenburg gubernia in honor of the Russian Army victories on the initiative of Governor General V. A. Obruchev and by the Tsar order [18]. There were three redoubts between each two settlements. Each fortification was surrounded by a ditch and a rampart, to be more exact, a breastwork of earth with gates [19].

By memoires of the contemporaries, the Cossack stanitsas from the very beginning had regular plans and rectangular network of streets, which was facilitated by the topographic conditions of steppe area. Usually each settlement had from one to three hundred households. They were divided into "ends" with their own names. The population usually comprised several groups of different nationalities, as the Cossacks were transferred there from different troops. Soldiers of line battalions from fortress garrisons were transferred into the Cossack estate received 5 rubles of travelling allowance and moved to the Novolineyniy region with their families. Governor V. A. Perovskiy abolished the Cossack 
stanitsas of internal cantons in Ufimskiy and Buzulukskiy uezds and ordered their residents to move to Novolineyniy region. According to the plan of military administration, the total of 3752 male Cossacks were to move from Bakalinskaya, Buzulukskaya, Nagaybakskaya, Olshanskaya, Samarskaya, Sorochinskaya, Tabynskaya, Totskaya, Ufimskaya and Alekseevskaya stanitsas [20].

The military character of settlements was marked by a historian of Orenburg Cossack troops F. M. Starikov. In towns, all buildings were wooden, made of logs and surrounded with a rampart of earth. To watch the steppe, platforms on four high columns were constructed, quite often barrows were made [2, 9]. After the nomads attacked Elizavetinskaya stanitsa in August 1844, all settlements of Novolineyniy region were surrounded with ditches and ramparts of earth with gun slots.

Parizh settlement was founded in 1842 as post No. 4 of the Cossack troops. In 1843, stanitsa was named after the French capital. Today, the settlement has 1712 residents. Most of the settlement's population is Nagaybaks - representatives of a minor ethnic group.

Actually, Nagaybaks are Tatars who went over to Orthodoxy as early as during the times of Ivan the Terrible. They are the descendants of the people of the Nogay Horde who lived in Kazan at Arsk Gates and assimilated with the local Tatars. Today, there are about ten thousand Nagaybaks on the territory of the former Orenburg gubernia, including in the former Novolineyniy region (on the territory of the modern Chelyabinsk oblast) -8148 people by the 2010 census. They are known for their peculiar language and culture. In 1736, the Empress Anna Ioanovna exempted Nagaybaks from taxes for their loyalty to the government; they were given lands and turned into the Cossack estate.

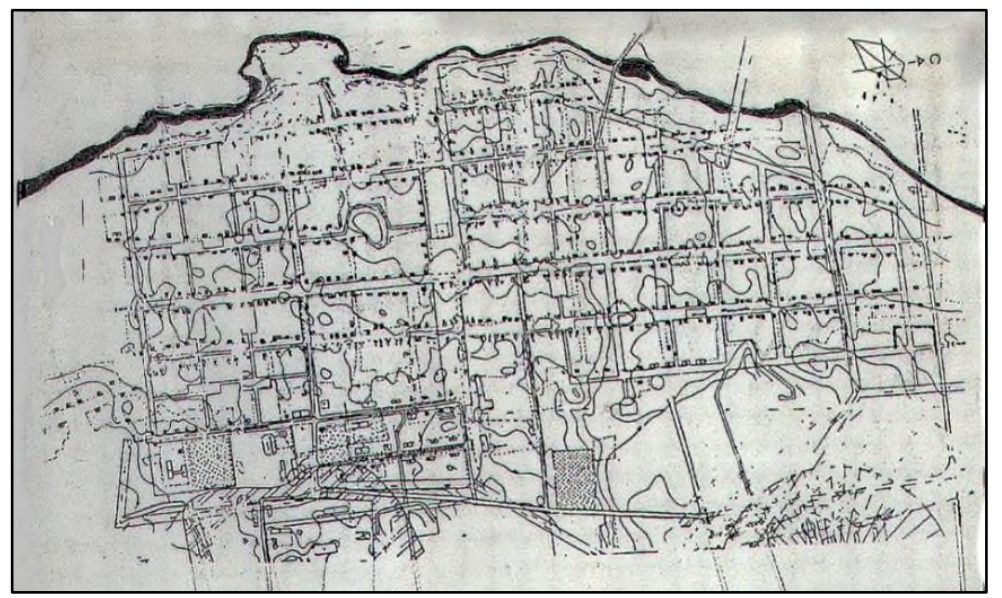

Fig. 2. General layout of Parizh settlement.

Parizh has always been a rather small settlement; today it counts about 800 houses and 11 streets. Initially, the settlement was formed along the central street, other streets parallel to it. Alleys go perpendicular to them, forming a regular settlement with square homesteads. Parizh was a stanitsa rare for Orenburg gubernia, where streets had names from the very beginning. In the Soviet period, previous names were changed, except for the central street Forshtadt (Fig. 2). In the stanitsa center, there is a broad perpendicular, leading to the large Cossack assembly square (Fig. 3, 4). On the square, there used to be a wooden Kosma and Damian church, which was not preserved [21].

The most popular type of Nagaybaks' log houses were two-chamber ones, with a main part and an entrance hall. The residential part of the building was also a kitchen. Roofs were often covered with birch bark. Decorative carvings of cornices and façade window frames were made of imported linden boards. 


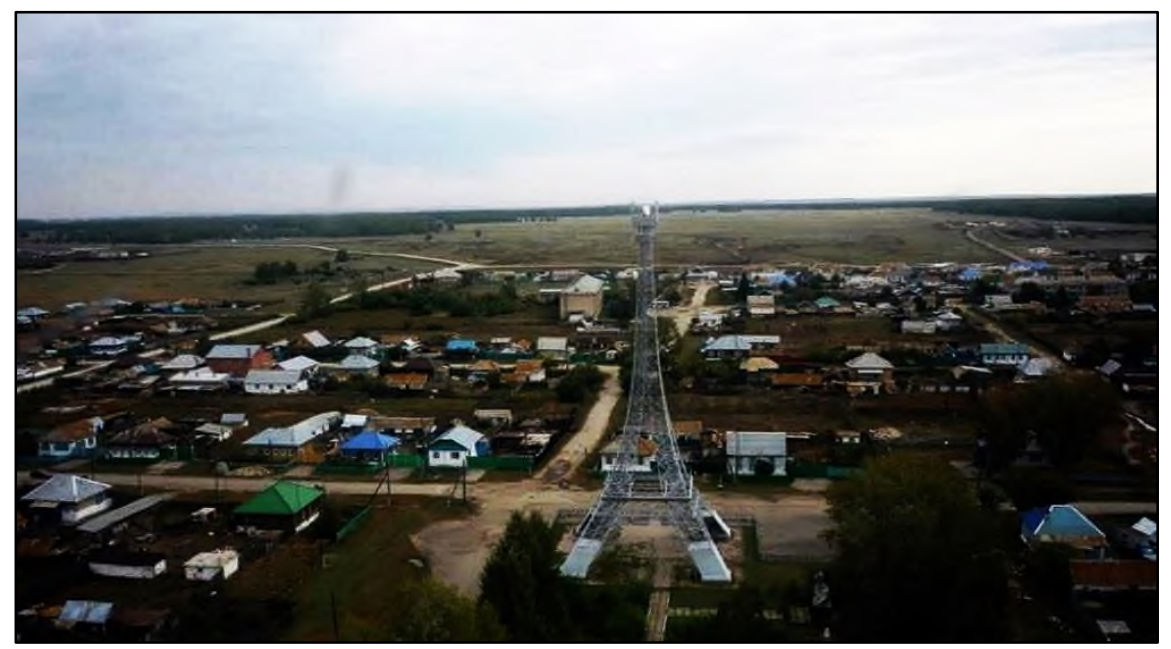

Fig. 3. Panorama of Parizh settlement. Photograph by E.V. Ponomarenko.

The inner planning and furniture of Nagaybaks' dwelling houses corresponds to the traditions of the Volga Tatars and the Russian Cossacks. There were plank beds and a stove with a cauldron built into it. The national feature of a Nagaybaks' dwelling house is a plank bed at the entrance opposite a stove - "uly-seke". Nagaybaks often had summer kitchens in their homesteads. An interior of one of such kitchen is preserved. Often, the initial, temporary dwelling buildings were turned into summer kitchens. For example, in M. E. Ivanova's homestead, a small one-chamber log house with an entrance hall, built by the lady's grandfather, was turned into a summer kitchen after the new large house was built. In that summer kitchen, a traditional Nagaybaks' interior is preserved: a Russian stove with an additional furnace and a built-in cauldron, and a plank bed. Two windows with shutters in the end wall face the street, two more - the yard. In the yard, near the entrance to the summer kitchen, there is an open stove with a cooker.

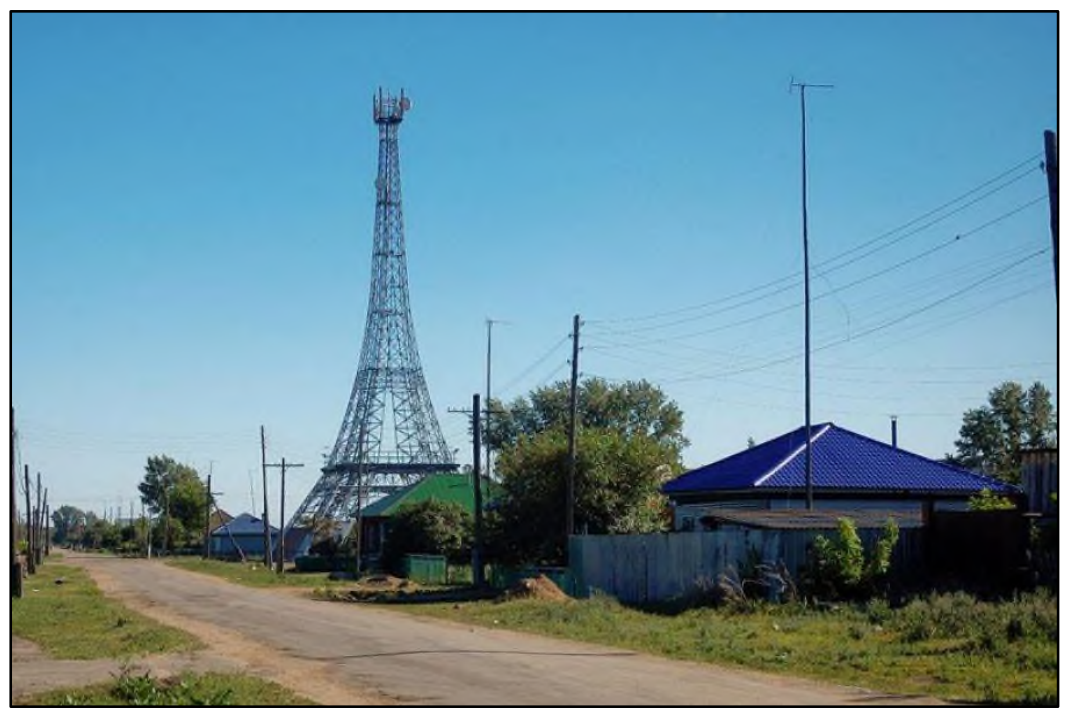

Fig. 4. Central street of Parizh settlement. Photograph by E.V. Ponomarenko. 
In homesteads, there were wooden bathhouses. In an abandoned homestead, an adobe bathhouse was preserved. It has a dressing-room, the main room with a stove and a built-in cauldron, and an aperture in the roof for installing a shower.

Today, there are historical and new private houses, mainly one-storeyed. In the centre, there are several two-storeyed houses built in the 1960-s. a typical example is «Parizh settlement history museum», located in a preserved Cossack homestead (Fig. 5). In 2005, on the Cossack assembly square, on the site of the demolished church, "Uralsvyazinform» cellular operator erected a replica of the Eiffel tower six times smaller than the original. Its height is 50 meters (Fig. 5). This construction provokes interest of the population but does not fit the ensemble of the settlement. On the other hand, the advantage is that another asphalt road appeared in the settlement due to this construction.

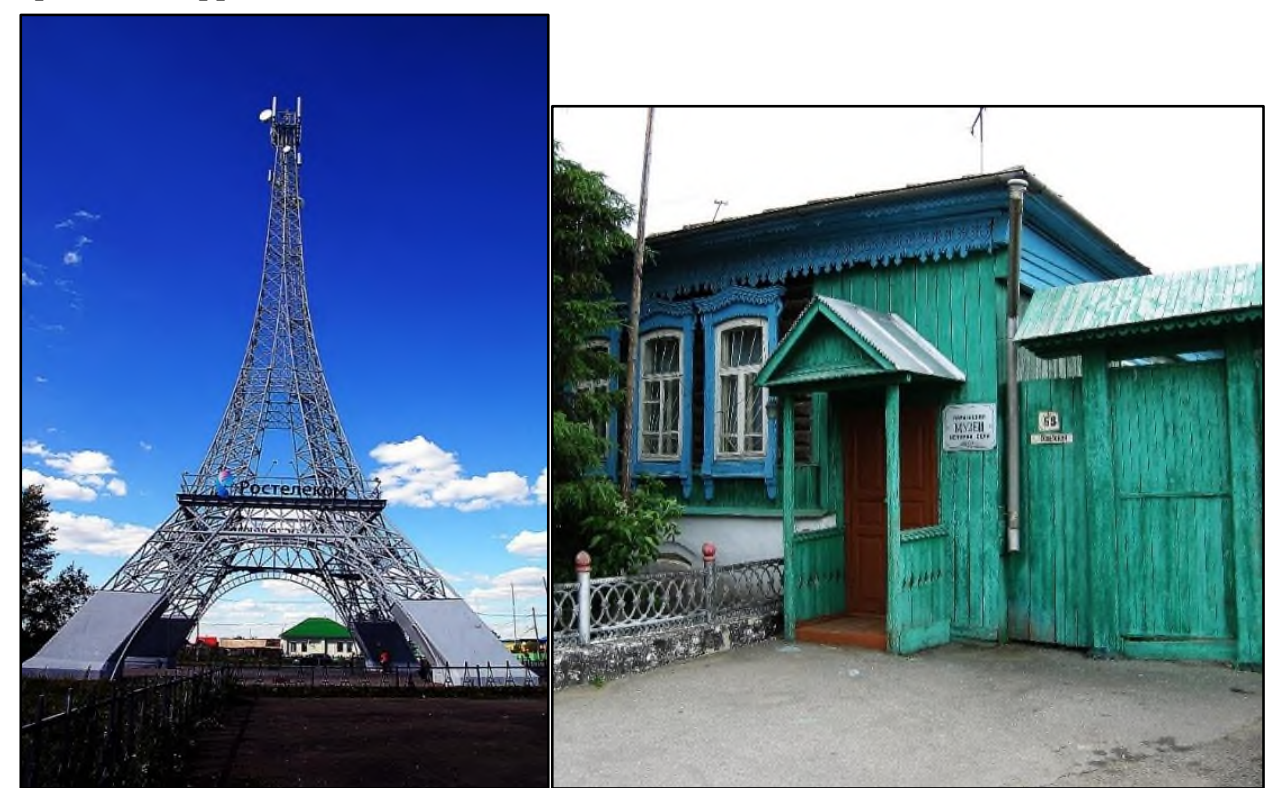

Fig. 5. Buildings in Parizh settlement. Photograph by E.V. Ponomarenko.

\section{Discussion}

There are very few researches devoted to the architecture of the Cossack stanitsas of Orenburg gubernia. There are mainly works by historians and local history experts, focusing on topics other than architecture. The most interesting are works by William C. Brumfield 2004, 2015, 2017 [22, 23, 24], A. P. Abramovskiy and V. S. Kobzov 1999 [25], I. R. Atnagulov 2004 [26], M. P. Mochalova 1978 [27], Y. T. Mukhamedshin 1995 [28], and A. A. Rybalko 2007 [29], giving some information about dwelling houses of some settlements in Novolineyniy region and other Cossack stanitsas all over the Urals.

The only work by a Russian architect, written by the data of $1970-\mathrm{s}$, is a book by M. P. Mochalova (1978) «Na poludennuyu storonu» («To the southern lands»), devoted to the architecture of the Southern Urals in general. The author touched upon only one aspect of the studied topic - planning of some Cossack settlements of Chelyabinsk oblast, among which only Leyptsig is mentioned. The character of buildings and ensembles of settlements were not considered.

The works by foreign architects actually do not touch upon the Southern Urals. The only one to consider the Urals was Professor of Slavonic Studies of Tulane University in New Orleans (Louisiana, USA) William C. Brumfield, but he did not touch upon the 
Southern Urals. In his fundamental book "A History of Russian Architecture", the author thoroughly analyzes the development of Russian architecture, and in the article "From Victor Hugo to Fedor Dostoevskii: 19th-Century Perceptions of Architecture as Historical Text" he substantiates the connection between ancient architectural traditions and the 19th century construction in Russia: "If nationalism is a secular religion, it is appropriate that the revival of medieval architecture in 19th-century European eclecticism involved the transposition of stylistic motifs from religious to secular structures. This is especially evident in late 19th-century Russia, whose masonry architecture before the 18th century consisted almost entirely of churches» [23, 24]. Brumfield considered individual monuments in historical context in his article "Gateway to Siberia: the Architectural Heritage of Verkhoturye and Ekaterinburg", but he researched nothing to the south of Ekaterinburg.

Actually significant works on the Cossacks of Novolineyniy region were only written by historians. But historical studies have these own priorities in researches of artistic traditions of ethnoses, which only fragmentarily touch upon architecture. The most prominent historians of the region A. P. Abramovskiy and V. S. Kobzov in their monograph «Orenburgskoye kazachye voysko v trekh vekakh» («Orenburg Cossack troops during three centuries») dealt with the issues of forming the defense system in the Russian south-eastern boundaries, of the system of governance and military service of the Orenburg Cossacks. They paid special attention to the issues of civil and military governance, interrelations between people of different nationalities, while architecture was mentioned in passing, without research and conclusions. For example, «The nomads continuously terrorized the Cossacks with their attacks at stanitsas, capture of people and cattle, arsons of fields... In ten years of living in the New Line, the Orenburg Cossacks lost over 2000 people» [25].

A historian I. R. Atnagulov rather thoroughly examined the Cossack settlements and analyzed the stages of forming the economic setup of the Cossacks: «The main providing type of Nagaybaks' economy was ploughed field agriculture. However, unlike peasants, they served in the Orenburg Cossack Army, i.e., were state servants. This had an impact on certain features of the Nagaybaks' settlements. ... Since their foundation, the Nagaybaks' habitations had the character of fortified settlements (fortresses). The restless frontier between the Kazakhs and the Bashkirs compelled the Cossacks to arrange all elements of their settlements maximally compactly» [26].

Yu. T. Mukhamedshin researched the history of Cossacks and their relation with nomadic Kazakhs: «In 1845, the Kazakhs captured 8 horses pastured near Poltavskiy settlement. In 1846, they captured two herds (over 500 horses) belonging to the Cossacks of settlements Elizavetpolskiy and Parizhskiy. They preserved their traditional setup. They got the right to build permanent dwellings on the lands allotted for them, to spend winters there, and in summers move (along the commonly used driftways) to summer pastures beyond the New Line (upper reaches of the Tobol, Or, Irgiz, Ilek rivers)» [28].

Many interesting facts about the life of Cossacks are given in the works by A. A. Rybalko devoted to the traditional material culture of the Southern Urals people in the end of the 19th - beginning of the 20th cc. For example, he marked that «Stone walls with clay mortar were strengthened with buttresses at the especially large barns (Parizh settlement)» and «The household utensils of the Orenburg Cossacks are, first of all, kitchenware: castiron pots of various sizes and purposes, mainly manufactured in the local plants in the Southern Urals» [29].

All the above works analyze individual buildings in the Cossack stanitsas from the viewpoint of history, history of construction, or modern condition of certain monuments. Their authors did not analyze the main stages and features of development of the Cossack 
stanitsas of Novolineyniy region of Orenburg gubernia or evolution of architectural forms of their buildings.

Our research emphasizes the necessity to preserve the architectural and town-planning traditions of the Southern Urals and to use them in new constructions. The architectural and town-planning monuments, carrying the spiritual messages of the past, are the witnesses of century-long traditions. A monument is inseparable from the history of which it is a witness and from the environment where it is located. As our research showed, the awareness of the heritage value is constantly increasing in the region, being viewed as belonging to everyone. It is a part of the common global and Russian process. The monuments of architecture and town-planning reflect the history of various ethnic groups in the region. Today, the interest in national features of settlements planning and construction is evergrowing.

In general, the modern reconstruction and restoration of the Cossack settlements of Orenburg gubernia are characterized by inconsistency between a great desire to revive "the spirit of the place", the underlying ethnic traditions and culture, on the one hand, and a lack of professional knowledge in architect, on the other. The practicing architects still know little about the regional architectural and town-planning traditions and do not follow them. There are very few conservation architects in the region; their attestation is abolished. Widely spread is the practice of citing not regional but global architectural patterns of various styles.

\section{Conclusion}

In general, linear planning is characteristic for stanitsas Parizh. The center of a Cossack stanitsa composition was a large square (a ground for trick riding and the Cossack assembly). This square was situated in the center of a settlement and was both an administrative and market center. A church, a school, stanitsa administration, a bar and other public buildings were located there.

\section{References}

1. V. M. Cheremshanskiy, Description of Orenburg gubernia in statistical, ethnographic and industrial aspects (1859)

2. F. M. Starikov, Where the Cossacks come from (historical sketch) (Printing house Efimovskogo-Mirovitskogo, Orenburg, 1881)

3. V. N. Vitevskiy, Nagaybaks of Verkhneuralskiy uezd of Orenburg gubernia (VolgoKam word, 14, 72, 80, 138, 144, 1882)

4. V. N. Vitevskiy, I. I. Neplyuev and Orenburg region in its composition before 1758 (Printing house V. M. Klyuchnikova, Kazan, 1897)

5. P. I. Rychkov, Topography of Orenburg gubernia (Publishing house Orenb. Provincial stat. committee, Orenburg, 1887)

6. N. M. Chernavskiy, Orenburg eparchy in its past and present, Printing house of the Orenburg spiritual consistory 1 (1900)

7. E. A. Bekteeva, Nagaybaks (Baptizeed Tatars of Orenburg gubernia) (Living antiquity. Saint Petersburg, 1902)

8. D. K. Zelenin, At the Orenburg Cossacks, Ethnographic review 4 (1905)

9. M. A. Krukovskiy, The Southern Urals, Traveler's sketches (K. I. Tikhomirova. Moscow, 1909) 
10. I. Krivoshchekov, Rituals and customs of the Orenburg Cossacks, Orenburg County Herald 1-7 (1915)

11. Orenburg Eparchial Bulletin 10 (1876)

12. Orenburg Eparchial Bulletin 49 (1911)

13. Orenburg Eparchial Bulletin 32-33 (1912)

14. M. D. Golubykh, Cossack village (1930)

15. E. E. Blomkvist, Peasants' buildings of the Russians, Ukrainians and Belorussian (settlements, residential houses and household premises) East Slavic ethnographic collection 73-485 (1956)

16. Russian State Archive of ancient acts, foundation 248, Inventory 160, Storage unit 335.

17. V. V. Zverinskiy, Orenburg gubernia. List of inhabited places by 1866 (1871)

18. State Archive of Orenburg oblast, foundation 6, Inventory 10, Storage unit 4570, sheet 3.

19. State Archive of Orenburg oblast, foundation 6, Inventory 10, Storage unit 4570, sheet 1 .

20. United State Archive of Chelyabinsk oblast, foundation 87, Inventory 1, Storage unit 1432.

21. State Archive of Orenburg oblast, foundation 6, Inventory 10, Storage unit 5273, 1. 1068.

22. W. C. Brumfield, A History of Russian Architecture (University of Washington Press. Seattle, WA (USA), 2004)

23. W. C. Brumfield, From Victor Hugo to Fedor Dostoevskii: 19th-Century Perceptions of Architecture as Historical Text, Journal of Siberian Federal University. Humanities \& Social Sciences 6, 1026-1036 (2015)

24. W C. Brumfield, Gateway to Siberia: the Architectural Heritage of Verkhoturye and Ekaterinburg, Journal of Siberian Federal University. Humanities \& Social Sciences 5, 612-640 (2017)

25. P. Abramovskiy, V. S. Kobzov, Orenburg Cossack troops during three centuries (Chelyabinsk State University, 1999)

26. R. Atnagulov, Settlements and residential houses of Cossacks-nagaybaks of the second half of the 19th - beginning of the 20th cc, Archaeology, Anthropology and Ethnography of Eurasia 4, 20, 149-160 (2004)

27. M. P. Mochalova, To the southern lands (1978)

28. Y. T. Mukhamedshin, Ethnographic review of constructions and types of residential houses of nagaybaks and their closest neighbors (Nagaybaki, 1995)

29. A. Rybalko, Traditional residential house of Orenburg Cossacks, Ural the craftsman. Traditional material culture of the peoples of the Southern Urals of the end of the 19th - beginning of the 20th cc (Krokus. Chelyabinsk, 2007) 